\title{
Late onset bilateral angioma serpiginosum involving upper limbs in a male: a rare presentation
}

\section{Rzadki przypadek naczyniaka pełzakowatego o późnym początku z obustronnym zajęciem kończyn górnych u pacjenta płci męskiej}

\author{
Tasleem Arif, Mohammad Adil, Syed Suhail Amin, Konchok Dorjay, Mohd. Mohtashim \\ Jawaharlal Nehru Medical College (JNMC), Aligarh Muslim University (AMU), Aligarh, India \\ Jawaharlal Nehru Medical College (JNMC), Aligarh Muslim University (AMU), Aligarh, Indie
}

Dermatol Rev/Przegl Dermatol 2017, 104, 348-35।

DOI: https://doi.org/l0.5। |4/dr.2017.68783

Angioma serpiginosum (AS) is a rare vascular disorder characterized by punctate red macules in a nevoid distribution arranged in groups to form a serpiginous pattern [1]. The disease is usually seen in late childhood in females and mostly occurs unilaterally over the lower extremity.

We report a case of bilateral AS on the upper extremities and chest in a 22-year-old male patient. Late onset (over 20 years of age), bilaterality, male sex and involvement of upper extremity add rarity to our case presentation and warrant its reporting.

A 22-year-old male presented with asymptomatic, red coloured lesions over the right side of chest and both arms. The lesions initially began on the chest one year back and gradually spread to involve the right and left arms. The patient was otherwise apparently healthy, and no family history of a similar disease was present. On physical examination, he was found to have multiple, punctate, grouped, red macules over the anterolateral chest on the right side, extending from just above the nipple to the anterior axillary fold and both upper arms up to the mid-forearms in a serpiginous pattern (Figs. $1 \mathrm{~A}-\mathrm{C}$ ). The lesions were not blanchable on diascopy. However, Darier's sign was negative. The rest of the cutaneous and systemic examination was unremarkable. Laboratory tests including blood counts and serum biochemistry were within the normal range. Serum testosterone and oestrogen levels were normal. Skin biopsy from the chest showed normal epidermis and dilated tortuous vessels in the upper dermis and dermal papillae, without inflammation or pigment deposition (Fig. 2). Toluidine blue stain for mast cells did not reveal any infiltrating mast cells. Based on the clinical
Naczyniak pełzakowaty (angioma serpiginosum - AS) jest rzadkim schorzeniem naczyniowym, charakteryzuje się obecnością punkcikowatych czerwonych plamek o rozmieszczeniu newoidalnym, występujących w skupiskach, szerzących się obwodowo [1]. Choroba pojawia się zwykle w okresie późnego dzieciństwa u dziewczynek i przebiega zazwyczaj z zajęciem kończyny dolnej po jednej stronie ciała.

W pracy opisano przypadek 22-letniego pacjenta płci męskiej, u którego rozpoznano AS zlokalizowanego obustronnie w obrębie kończyn górnych i klatki piersiowej. Przypadek zasługuje na uwagę ze względu na późny początek choroby (po 20. roku życia), obustronne zajęcie skóry kończyn górnych oraz płeć męską pacjenta.

U 22-letniego mężczyzny wystąpiły bezobjawowe, czerwone zmiany skórne umiejscowione po prawej stronie klatki piersiowej oraz na obu ramionach. Zmiany pojawiły się po raz pierwszy rok wcześniej, początkowo na skórze klatki piersiowej, skąd rozprzestrzeniły się stopniowo na prawe i lewe ramię. Poza objawami skórnymi pacjent był zdrowy. W wywiadzie rodzinnym nie było przypadków podobnego schorzenia. Badanie fizykalne wykazało liczne punkcikowate, czerwone plamki występujące w skupiskach na skórze powierzchni przednio-bocznej klatki piersiowej po prawej stronie. Zmiany rozciągały się od obszaru tuż powyżej brodawki sutkowej aż po fałd pachowy przedni, z zajęciem obu kończyn górnych aż po środkową część przedramion (ryc. 1 A-C). Zmiany nie bledły podczas diaskopii. Objaw Dariera był jednak ujemny. Poza tymi zmianami w badaniu skóry i badaniu ogólnym nie stwierdzono żadnych innych nieprawidłowości. Wyniki badań laboratoryjnych, m.in. morfologia krwi i badania biochemiczne, mieściły się w granicach normy. Stężenie testosteronu i estroge- 


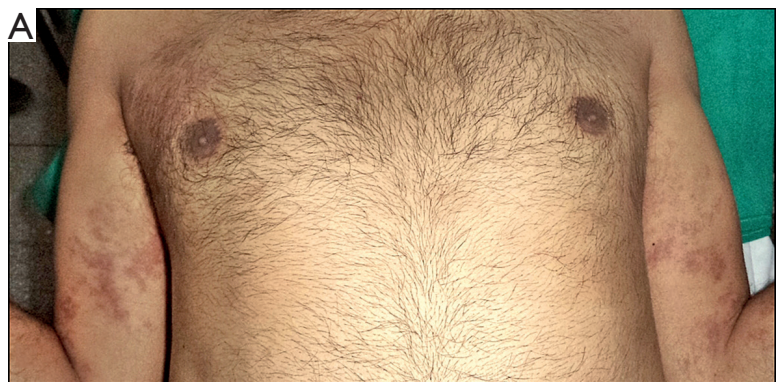

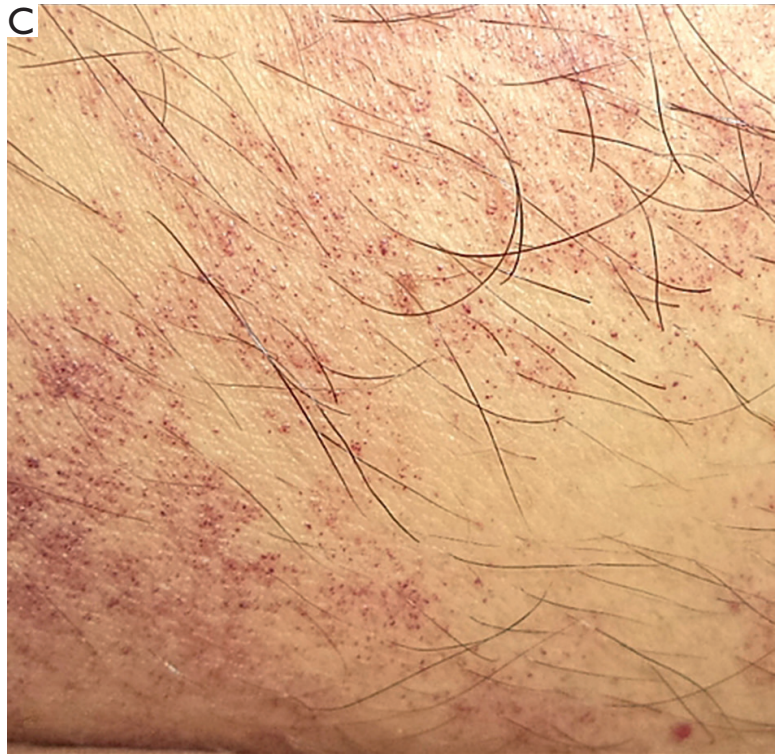

features and histopathology, the diagnosis of AS was made. The patient refused treatment after learning about the benign nature of the disease.

Angioma serpiginosum was first described in 1889 by Hutchinson as an infective nevoid disease and was named by Crocker a year later [2]. Around

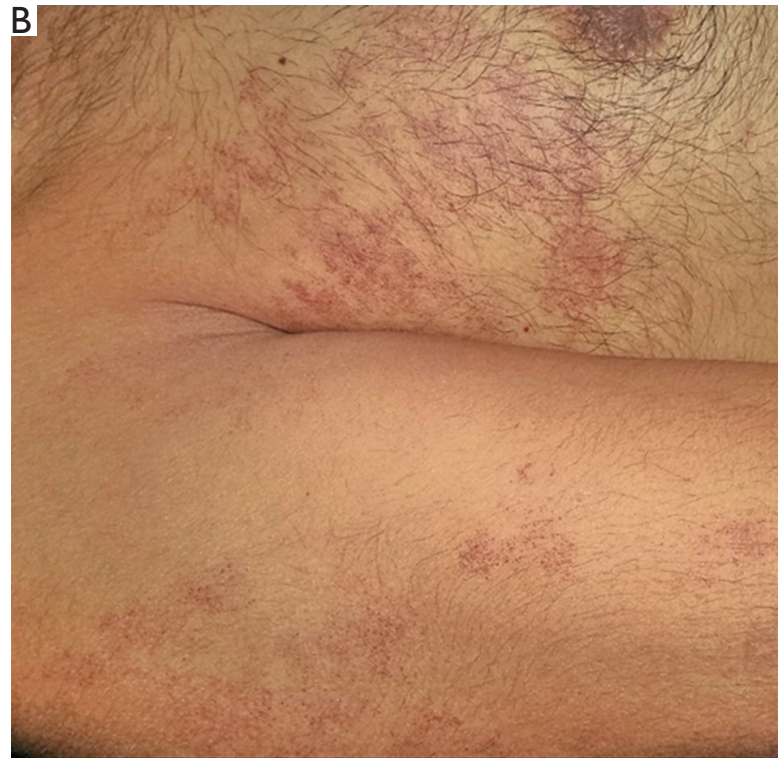

Figure I. Red punctate macules over the right side of chest and both arms (A, B) in a 22-year-old male. Closer view of reddish punctate macules (C)

Rycina I. Czerwone, punkcikowate plamki umiejscowione po prawej stronie klatki piersiowej i na obu ramionach (A, B) u 22-letniego pacjenta płci męskiej. Powiększony widok czerwonawych, punkcikowatych plamek (C)

nu w surowicy było prawidłowe. Biopsja skóry klatki piersiowej wykazała prawidłowy obraz naskórka oraz rozszerzone, kręte naczynia w warstwie brodawkowatej skóry właściwej, bez towarzyszącego stanu zapalnego i odkładania się pigmentu (ryc. 2). Barwienie komórek tucznych błękitem toluidynowym nie ujawniło obecno-

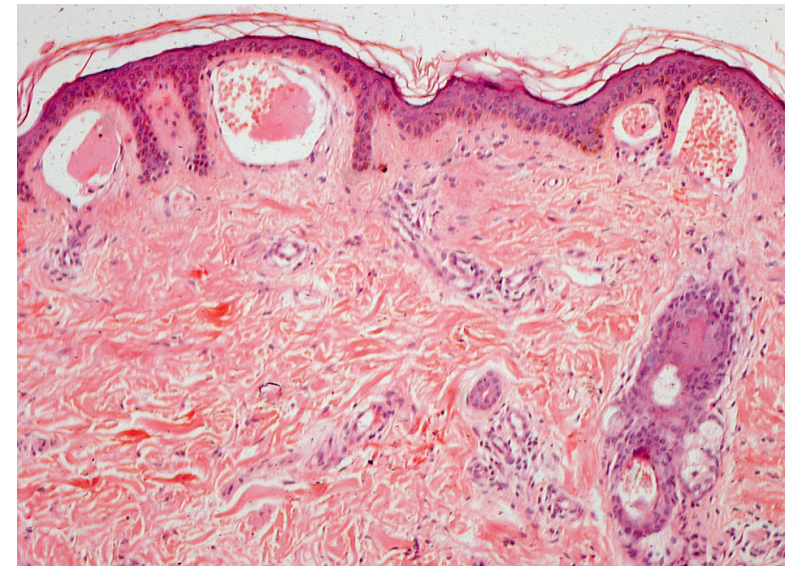

Figure 2. Histopathology showing dilated tortuous vessels in the papillary dermis without extravasation of red blood cells, inflammation or pigment deposition

Rycina 2. Obraz histopatologiczny z widocznymi rozszerzonymi, krętymi naczyniami w warstwie brodawkowatej skóry, bez wynaczynienia erytrocytów, stanu zapalnego i odkładania się barwnika 
$90 \%$ cases are seen in females, with $80 \%$ of all cases occurring under 20 years of age [2, 3]. Familial cases have been documented. Angioma serpiginosum involves the lower extremities in most cases, but any site can be involved with usual sparing of the mucocutaneous junctions, palms and soles. Involvement of the eye and nervous system has been reported, too [4]. Involvement in a Blaschkoid pattern may be seen [5]. Bilateral involvement is usually seen in those cases where there is extensive body surface area involvement $[6,7]$. We could not find any report with limited cutaneous involvement presenting bilaterally. Thus, the onset at over 20 years of age and bilateral involvement of the upper limbs in a male make our case a rare presentation.

The pathogenesis of AS is not known. Its occurrence at puberty, predominance in females and enlargement in pregnancy point to the role of oestrogen [5]. But the absence of oestrogen and progesterone receptors in the lesions rejects this view. Another theory proposes cold exposure-induced vascular damage and consequent proliferation and aggregation as the cause [8]. Our patient, however, did not have deranged hormones or history of cold exposure. Angioma serpiginosum is now believed to be a capillary malformation with endothelial proliferation [9].

Angioma serpiginosum presents as multiple, red, punctate lesions in small clusters and sheets with arrangement in a serpiginous pattern. Lesions show incomplete blanching with pressure. Dermoscopy shows well defined 'red lagoons' indicating dilated superficial capillaries [9]. However, dermoscopy was not done in our case due to unavailability. Histopathology shows dilated tortuous capillaries in the papillary dermis, without red cell extravasation or inflammation [10]. Electron microscopy demonstrates capillary walls filled with basement membrane-like material and collagen, indicating that AS is a capillary malformation [10].

The differential diagnosis of AS includes unilateral nevoid telangiectasia (UNT) syndrome, which follows a dermatomal distribution, shows telangiectatic vessels and blanches on diascopy. Pigmented purpuric dermatoses show extravasated erythrocytes, while angiokeratomas show hyperkeratosis and papillomatosis on histology. Telangiectasia macularis eruptiva perstans was excluded by the absence of mast cells on histopathology. Angioma serpiginosum is slowly progressive and shows partial spontaneous regression. Pulsed dye laser may be used for treatment [5].

The occurrence of AS in a male patient over 20 years of age, with bilateral distribution at an uncommon site (chest and upper limbs), are the unique features that prompted us to report this rare disease entity. ści nacieków. Na podstawie cech klinicznych i histopatologicznych ustalono rozpoznanie AS. Po poinformowaniu o łagodnym przebiegu schorzenia pacjent nie zdecydował się na podjęcie leczenia.

Naczyniak pełzakowaty został opisany po raz pierwszy przez Hutchinsona w 1889 r. jako zakaźna choroba skóry o charakterze newoidalnym i nazwany przez Crockera rok później [2]. Około 90\% przypadków stwierdza się u kobiet, a 80\% zachorowań występuje przed 20. rokiem życia [2, 3]. Potwierdzono rodzinne występowanie choroby. W większości przypadków AS obejmuje kończyny dolne. Schorzenie może się jednak pojawić w każdym miejscu, choć zazwyczaj przebiega bez zajęcia połączeń skórno-śluzówkowych, dłoni i podeszew stóp. W piśmiennictwie opisywano również przypadki zajęcia oka i układu nerwowego [4]. Zmiany mogą mieć układ zgodny z liniami Blaschko [5]. W przypadku zajęcia dużych obszarów skóry zazwyczaj stwierdza się obustronne występowanie choroby $[6,7]$. W piśmiennictwie nie odnaleziono żadnego przypadku obustronnego ograniczonego zajęcia skóry. Opisywany przypadek jest nietypowy, ponieważ dotyczy pacjenta płci męskiej, w wieku powyżej 20 lat, ze zmianami skórnymi obejmującymi obustronnie kończyny górne.

Patogeneza AS jest nieznana. Występowanie schorzenia w wieku dojrzewania, głównie u kobiet, a także nasilanie się zmian w ciąży może wskazywać na udział estrogenu w rozwoju AS [5]. Teorii tej zaprzecza jednak brak receptorów estrogenowych i progesteronowych w obrębie zmian. Według innej teorii AS ma związek z uszkodzeniem naczyń skóry wskutek narażenia na niskie temperatury, z następującą proliferacją i agregacją [8]. U przedstawionego pacjenta nie stwierdzono jednak zaburzeń hormonalnych i ekspozycji na niskie temperatury w wywiadzie. Obecnie uważa się, że AS stanowi malformację kapilarną o proliferacji śródbłonkowej [9].

Objawami choroby są liczne, czerwone, punkcikowate zmiany skórne występujące w niewielkich skupiskach, szerzące się obwodowo. Zmiany tylko częściowo bledną przy ucisku. W dermoskopii stwierdza się wyraźnie ograniczone zmiany przypominające "czerwone laguny", wskazujące na rozszerzenie naczyń kapilarnych w warstwie przypowierzchniowej skóry [9]. W opisywanym przypadku nie wykonano jednak badania dermoskopowego ze względu na brak takiej możliwości. W badaniu histopatologicznym wykazano rozszerzone, kręte naczynia w warstwie brodawkowatej skóry, bez wynaczynienia erytrocytów i stanu zapalnego [10]. W badaniu mikroskopem elektronowym stwierdza się malformację naczyń kapilarnych [10].

W diagnostyce różnicowej AS należy uwzględnić unilateral nevoid teleangiectasia, zespół charakteryzujący się zlokalizowanymi jednostronnie teleangiektazjami o układzie dermatomów, z widocznymi teleangiektycz- 


\section{CONFLICT OF INTEREST}

The authors declare no conflict of interest. nymi naczyniami krwionośnymi, blednącymi podczas diaskopii. W przedstawionym przypadku ze względu na nieobecność komórek tucznych w badaniu histopatologicznym wykluczono telangiectasia macularis eruptiva perstans. Naczyniak pełzakowaty cechuje się powolną progresją i częściowym samoistnym ustępowaniem. W leczeniu można stosować pulsacyjny laser barwnikowy [5].

Opisany przypadek AS zasługuje na uwage ze względu na pewne wyjątkowe cechy, m.in. wystąpienie schorzenia u pacjenta płci męskiej, w wieku powyżej 20 lat, z obustronnym zajęciem skóry w nietypowej lokalizacji (klatka piersiowa i kończyny górne).

\section{KONFLIKT INTERESÓW}

Autorzy deklarują brak konfliktu interesów.

\section{References}

\section{Piśmiennictwo}

1. Namazi M.R., Handjani F.: Angioma serpiginosum. Dermatol Online J 2003, 9, 19.

2. Chen J.H., Wang K.H., Hu C.H., Chiu J.S.: Atypical angioma serpiginosum. Yonsei Med J 2008, 49, 509-513.

3. Erkek E., Bozdogan O., Akarsu C., Atasoy P., Koçak M.: Absence of estrogen and progesterone receptors around the affected vessels of angioma serpiginosum: case report. Am J Clin Dermatol 2006, 7, 383-386.

4. Mukherjee S., Salphale P., Singh V.: Late onset angioma serpiginosum of the breast with co-existing cherry angioma. Indian Dermatol Online J 2014, 5, 316-319.

5. Das D., Nayak C.S., Tambe S.A.: Blaschko-linear angioma serpiginosum. Indian J Dermatol Venereol Leprol 2016, 82, $335-337$.

6. Agrawal S., Agarwalla A., Rizal A., Sinha A., Debberman K.: Angioma serpiginosum: a case report. Int J Dermatol 2004, 43, 917-918.

7. Katta R., Wagner A.: Angioma serpiginosum with extensive cutaneous involvement. J Am Acad Dermatol 2000, 42, $384-385$.

8. Neumann E.: Some new observations on the genesis of angioma serpiginosum. Acta Derm Venereol 1971, 51, 194-198.

9. Freites-Martinez A., Martinez-Sanchez D., Moreno-Torres A., Huerta-Brogeras M., Hernández-Núñez A., Borbujo J.: Angioma serpiginosum: report of an unusual acral case and review of the literature. An Bras Dermatol 2015, 90 (3 Suppl 1), S26-28.

10. Sancheti K., Das A., Podder I., Gharami R.C.: Angioma serpiginosum in a patchy and blaschkoid distribution: a rare condition with an unconventional presentation. Indian J Dermatol 2016, 61, 570-572.

Received: 15.11 .2016

Accepted: 5.06 .2017

Otrzymano: 15.11.2016 r

Zaakceptowano: $5.06 .2017 \mathrm{r}$.

How to cite this article

Arif T., Adil M., Amin S.S., Dorjay K., Mohtashim M.: Late onset bilateral angioma serpiginosum involving upper limbs in a male: a rare presentation. Dermatol Rev/Przegl Dermatol 2017, 104, 348-351. DOI: https://doi.org/10.5114/dr.2017.68783. 